\title{
Article \\ Antifungal Activity of $N$-(4-Halobenzyl)amides against Candida spp. and Molecular Modeling Studies
}

\author{
Yunierkis Perez-Castillo ${ }^{1}\left(\right.$, Ricardo Carneiro Montes ${ }^{2}\left({ }^{\circ}\right.$, Cecília Rocha da Silva $^{3}$, João Batista de Andrade Neto $^{3}$, \\ Celidarque da Silva Dias ${ }^{2}$, Allana Brunna Sucupira Duarte ${ }^{2} \mathbb{D}$, Hélio Vitoriano Nobre Júnior ${ }^{3}$ \\ and Damião Pergentino de Sousa $2, * \mathbb{D}$ \\ 1 Bio-Cheminformatics Research Group and Escuela de Ciencias Físicas y Matemáticas, Universidad de Las \\ Américas, Quito 170504, Ecuador; yunierkis@gmail.com \\ 2 Department of Pharmaceutical Sciences, Federal University of Paraíba, João Pessoa 58051-900, PB, Brazil; \\ ricsony_79@yahoo.com.br (R.C.M.); celidarque@ltf.ufpb.br (C.d.S.D.); allanabrunna@gmail.com (A.B.S.D.) \\ 3 Laboratory of Bioprospection in Antimicrobial Molecules (LABIMAN), Drug Research and Development \\ Center (NPDM), Federal University of Ceará, Fortaleza 60020-181, CE, Brazil; \\ ceciliarocha86@yahoo.com.br (C.R.d.S.); jb_andradeufc@hotmail.com (J.B.d.A.N.); \\ heliouf@@yahoo.com.br (H.V.N.J.) \\ * Correspondence: damiao_desousa@yahoo.com.br; Tel.: +55-83-3216-7502
}

\section{check for}

updates

Citation: Perez-Castillo, Y.; Montes, R.C.; da Silva, C.R.; Neto, J.B.d.A.; Dias, C.d.S.; Brunna Sucupira Duarte, A.; Júnior, H.V.N.; de Sousa, D.P. Antifungal Activity of $N$-(4-Halobenzyl)amides against Candida spp. and Molecular Modeling Studies. Int. J. Mol. Sci. 2021, 23, 419. https://doi.org/10.3390/ijms23010419 Academic Editor: Sugunadevi Sakkiah

Received: 9 October 2021 Accepted: 10 December 2021 Published: 31 December 2021

Publisher's Note: MDPI stays neutral with regard to jurisdictional claims in published maps and institutional affiliations.

Copyright: (c) 2021 by the authors. Licensee MDPI, Basel, Switzerland. This article is an open access article distributed under the terms and conditions of the Creative Commons Attribution (CC BY) license (https:// creativecommons.org/licenses/by/ $4.0 /)$.
Abstract: Fungal infections remain a high-incidence worldwide health problem that is aggravated by limited therapeutic options and the emergence of drug-resistant strains. Cinnamic and benzoic acid amides have previously shown bioactivity against different species belonging to the Candida genus. Here, 20 cinnamic and benzoic acid amides were synthesized and tested for inhibition of C. krusei ATCC 14243 and C. parapsilosis ATCC 22019. Five compounds inhibited the Candida strains tested, with compound $16(\mathrm{MIC}=7.8 \mu \mathrm{g} / \mathrm{mL})$ producing stronger antifungal activity than fluconazole (MIC $=16 \mu \mathrm{g} / \mathrm{mL}$ ) against . . krusei ATCC 14243. It was also tested against eight Candida strains, including five clinical strains resistant to fluconazole, and showed an inhibitory effect against all strains tested (MIC $=85.3-341.3 \mu \mathrm{g} / \mathrm{mL}$ ). The MIC value against $C$. $k r u s e i$ ATCC 6258 was $85.3 \mathrm{mcg} / \mathrm{mL}$, while against C. krusei ATCC 14243, it was 10.9 times smaller. This strain had greater sensitivity to the antifungal action of compound 16. The inhibition of C. krusei ATCC 14243 and C. parapsilosis ATCC 22019 was also achieved by compounds 2, 9, 12, 14 and 15. Computational experiments combining target fishing, molecular docking and molecular dynamics simulations were performed to study the potential mechanism of action of compound $\mathbf{1 6}$ against C. krusei. From these, a multi-target mechanism of action is proposed for this compound that involves proteins related to critical cellular processes such as the redox balance, kinases-mediated signaling, protein folding and cell wall synthesis. The modeling results might guide future experiments focusing on the wet-lab investigation of the mechanism of action of this series of compounds, as well as on the optimization of their inhibitory potency.

Keywords: antimicrobial activity; Candida auris; benzoic acid; fungi; cinnamic acid; natural products; plants; molecular docking; candidiasis; anticandidal drugs

\section{Introduction}

The yeasts of genus Candida cause several infectious diseases such as candidiasis [1] and candidemia [2]. These involve a wide spectrum of superficial and invasive opportunistic mycoses affecting patients exposed to a great diversity of risk factors [3], such as deficiency in host defense mechanisms, invasive medical procedures and impairment of anatomical barriers due to burns [4]. In the search for chemical agents that could defeat these endemics, benzoic acids and their derivatives have a peculiar power to inhibit the growth of some pathogenic fungi $[5,6]$. The inhibition of benzoate 4-hydroxylase, an enzyme responsible for aromatic detoxification, is a known route for benzoic mi- 
crobial inhibition [7]. Benzoic acids and their derivatives, such as gallic acid, an antiinflammatory and neuroprotective agent [8-11]; vanillic acid, which functions as a hepatoprotective agent [12] and cinnamaldehyde, a phenylpropanoid that has antimicrobial properties on Staphylococcus aureus strains as well as on gram-negative bacteria, are important therapeutic sources [13].

The occurrence of halogenated cinnamic and benzoic amides is not usual in plants, but research has been looking up for applied synthesis of these halogenated structures [14-18], which show important biological activities such as antitumoral properties, EGFR inhibition [19], stimulatory effects on insulin secretion [20] and melanogenesis inhibition [12]. Some halogenated amides have a high inhibitory antimicrobial activity, and it was proven that chlorinated cinnamic analogues possess higher microbial inhibition in bacterial and fungal strains than their fluorinated and brominated analogues [21]. In addition, benzoic derivatives of the type salicylanilides with ortho and para hydroxyl and meta methoxyl groups have increased microbial inhibitory activity [22].

On the other hand, computational methods have been widely applied for the prediction of potential targets of bioactive compounds. These are based on the information available in the literature and databases containing protein-ligand associations, employing either ligand- or structure-based methodologies [23-27]. Experimental evidence supporting the binding of compounds of interest to their computationally predicted targets has been provided elsewhere [28-30]. Furthermore, as computational power constantly increases, the large-scale post-processing of predicted ligand-target associations employing computationally demanding methods, such as molecular dynamics simulations, is becoming a routine task [31-33].

In previous works $[34,35]$, we performed the preparation of halogenated cinnamic and benzoic amides with benzotriazol-1-yloxy-tris[dimethylamino]phosphonium hexafluorophosphate (BOP) as a coupling agent $[36,37]$. In this work, we continue the prospection of their antifungal activity by evaluating the inhibitory capacity of halogenated amides in other strains of the Candida genus. The antifungal activity evaluations are followed by computational predictions to determine the possible mechanisms of action of the most potent compound in our experimental assays.

\section{Results}

\subsection{Chemistry}

The structures of amides 1-20 were consistent with the infrared spectra (IR), ${ }^{1} \mathrm{H}$ - and ${ }^{13} \mathrm{C}-\mathrm{NMR}$ and high-resolution mass spectra (MALDI) data, according to previous work [34]. The estimated purity values of the amides were at $92-96 \%$ by ${ }^{1} \mathrm{H}-\mathrm{NMR}$ [38]. Products 1-11 are 4-chlorobenzylamides with cinnamic skeletal structure, and compounds 12-20 are $\mathrm{N}$-(4-halobenzyl)amides with benzoic skeletal structure. The synthesis of the products was conducted by the same procedures as those in Scheme 1 .<smiles>CCN(C)C(C)(C)C(F)(F)F</smiles>

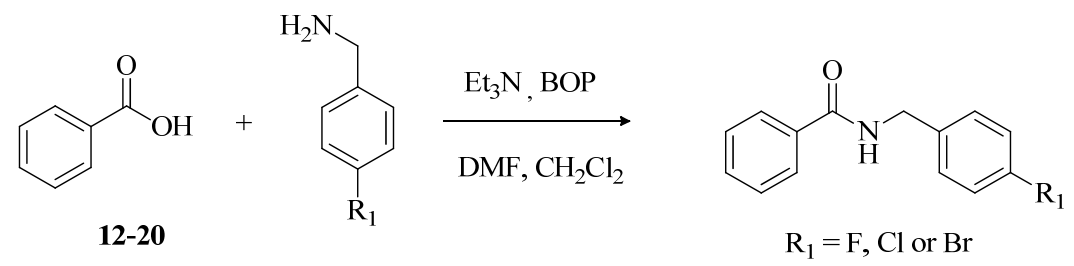

Scheme 1. General procedure for synthesis of halogenated amides. 


\subsection{Antimicrobial Activity}

In the antifungal study, the samples tested on the fungal strains C. parapsilosis (ATCC 22019) and C. krusei (ATCC 14243) were analyzed, and the results are shown in Table 1. The MICs of the compounds were significantly different, ranging from 250 to $7.8 \mu \mathrm{g} / \mathrm{mL}$. The MIC is the representation of the geometric mean of two distinct experiments on two different days. According to Table 1, the relevant MICs in the inhibition of C. parapsilosis were achieved by compounds $\mathbf{1 5}$ and $\mathbf{9}$ with $250 \mu \mathrm{g} / \mathrm{mL}$, compounds $\mathbf{1 2}$ and $\mathbf{1 6}$ with $150 \mu \mathrm{g} / \mathrm{mL}$ and compounds 2 and $\mathbf{1 4}$ with $31.25 \mu \mathrm{g} / \mathrm{mL}$, while in the inhibition of C. krusei, an MIC of $250 \mu \mathrm{g} / \mathrm{mL}$ was obtained for compounds 2, 12 and 15, an MIC of $150 \mu \mathrm{g} / \mathrm{mL}$ for $\mathbf{9}$, an MIC of $31.25 \mu \mathrm{g} / \mathrm{mL}$ for $\mathbf{1 4}$ and an MIC of $7.8 \mu \mathrm{g} / \mathrm{mL}$ for $\mathbf{1 6 .}$

Table 1. Evaluation of MIC $(\mu \mathrm{g} / \mathrm{mL})$ of the amides derived from cinnamic and benzoic acids in the broth microdilution assay.

\begin{tabular}{|c|c|c|c|c|c|c|c|}
\hline \multirow[b]{3}{*}{ Compounds } & \multirow[b]{3}{*}{$\mathbf{R}_{\mathbf{1}}$} & \multirow{3}{*}{$1-11$} & \multirow[b]{3}{*}{$\mathbf{R}_{\mathbf{3}}$} & $\mathrm{R}_{5}$ & & $\mathrm{R}_{2}$ & $\mathrm{R}_{5}$ \\
\hline & & & & & & \multicolumn{2}{|c|}{$\mathrm{MIC}^{1}$} \\
\hline & & & & $\mathbf{R}_{4}$ & $\mathbf{R}_{5}$ & $\begin{array}{l}\text { C. parapsilosis } \\
\text { (ATCC 22019) }\end{array}$ & $\begin{array}{c}\text { C. } k r u s e i \\
\text { (ATCC 14243) }\end{array}$ \\
\hline 1 & - & - & - & - & $\mathrm{Cl}$ & + & + \\
\hline 2 & - & $\mathrm{OH}$ & $\mathrm{OH}$ & - & $\mathrm{Cl}$ & 31.25 & 250 \\
\hline 3 & - & $\mathrm{OCH}_{3}$ & $\mathrm{OH}$ & - & $\mathrm{Cl}$ & + & + \\
\hline 4 & - & - & $\mathrm{OCH}_{3}$ & - & $\mathrm{Cl}$ & + & + \\
\hline 5 & $\mathrm{OH}$ & - & - & - & $\mathrm{Cl}$ & + & + \\
\hline 6 & - & $\mathrm{OH}$ & - & - & $\mathrm{Cl}$ & + & + \\
\hline 7 & - & - & $\mathrm{OH}$ & - & $\mathrm{Cl}$ & + & + \\
\hline 8 & - & - & $\mathrm{Cl}$ & - & $\mathrm{Cl}$ & + & + \\
\hline 9 & - & $\mathrm{OCH}_{3}$ & $\mathrm{OH}$ & $\mathrm{OCH}_{3}$ & $\mathrm{Cl}$ & 250 & 150 \\
\hline 10 & $\mathrm{NO}_{2}$ & - & - & - & $\mathrm{Cl}$ & + & + \\
\hline 11 & - & $\mathrm{OCH}_{3}$ & $\mathrm{OCH}_{3}$ & $\mathrm{OCH}_{3}$ & $\mathrm{Cl}$ & + & + \\
\hline 12 & - & - & - & - & $\mathrm{Cl}$ & 125 & 250 \\
\hline 13 & - & - & $\mathrm{C}_{6} \mathrm{H}_{5}$ & - & $\mathrm{Cl}$ & + & + \\
\hline 14 & - & $\mathrm{OCH}_{3}$ & $\mathrm{OH}$ & $\mathrm{OCH}_{3}$ & $\mathrm{Cl}$ & 31.25 & 31.25 \\
\hline 15 & - & - & $\mathrm{OH}$ & - & $\mathrm{Cl}$ & 250 & 250 \\
\hline 16 & - & $\mathrm{C}\left(\mathrm{CH}_{3}\right)_{3}$ & $\mathrm{OH}$ & $\mathrm{C}\left(\mathrm{CH}_{3}\right)_{3}$ & $\mathrm{Cl}$ & 125 & 7.8 \\
\hline 17 & - & $\mathrm{OH}$ & - & $\mathrm{OCH}_{3}$ & $\mathrm{Cl}$ & + & + \\
\hline 18 & - & $\mathrm{CH}_{3}$ & - & $\mathrm{NO}_{2}$ & $\mathrm{Cl}$ & + & + \\
\hline 19 & - & $\mathrm{OCH}_{3}$ & $\mathrm{OH}$ & - & $\mathrm{F}$ & + & + \\
\hline 20 & - & $\mathrm{OCH}_{3}$ & $\mathrm{OH}$ & - & $\mathrm{Br}$ & + & + \\
\hline Fluconazole & - & - & - & - & & 2 & 16 \\
\hline Voriconazole & - & - & - & - & & 0.125 & 0.25 \\
\hline
\end{tabular}

+ Growth of the microorganism; ${ }^{1}$ MIC was defined in $\mu \mathrm{g} / \mathrm{mL}$ and was considered the lowest concentration that produced $50 \%$ reduction in fungal cell growth after $24 \mathrm{~h}$ of incubation.

\subsection{Antifungal Activity of Compound $\mathbf{1 6}$}

The amide 16 was selected to test against several Candida strains, including five clinical strains resistant to fluconazole (Table 2). The compound 16 exhibits antimicrobial activity against all strains tested, with MICs ranging from 85.3 to $341.3 \mu \mathrm{g} / \mathrm{mL}$. 
Table 2. Minimum inhibitory concentrations (MICs) of compound 16 against Candida spp.

\begin{tabular}{cc}
\hline & MIC $^{\mathbf{5 0}}$ \\
\hline Strains $^{\text {a }}$ & Compound 16 $^{\mathbf{b}}$ \\
\hline C. parapsilosis ATCC 22019 & $106.6 \mu \mathrm{g} / \mathrm{mL}$ \\
C. krusei ATCC 6258 & $85.3 \mu \mathrm{g} / \mathrm{mL}$ \\
C. auris 01256P CDC & $85.3 \mu \mathrm{g} / \mathrm{mL}$ \\
C. albicans 1 & $341.3 \mu \mathrm{g} / \mathrm{mL}$ \\
C. albicans 2 & $128 \mu \mathrm{g} / \mathrm{mL}$ \\
C. tropicalis & $106.6 \mu \mathrm{g} / \mathrm{mL}$ \\
C. parapsilosis & $128 \mu \mathrm{g} / \mathrm{mL}$ \\
C. glabrata & $128 \mu \mathrm{g} / \mathrm{mL}$ \\
\hline
\end{tabular}

a Isolated collection yeast strains; ${ }^{\mathrm{b}}$ MIC was defined as the lowest concentration that produced $50 \%$ reduction in fungal cell growth after $24 \mathrm{~h}$. Note: the DMSO concentration in the well referring to $1024 \mu \mathrm{g} / \mathrm{mL}$ was below $2.5 \%$, showing no activity and no interference in the tests.

\subsection{Molecular Modeling}

The list of potential targets for compound $\mathbf{1 6}$ in C. krusei, selected as described in the Material and Methods section, is provided in Table 3. From the 37 selected proteins, 17 were identified through the computational target fishing approach, while the remaining 20 belong to the ergosterol synthesis pathway. Homology models were generated for all the proteins. The templates used in the homology models, the coverage of the query sequences by the templates and the values of the QMEAN scores of the models are provided as Supplementary Materials in Table S1. Among all targets, the models for seven of them (ERG6, ERG26, ERG4, ERG5, ERG3, ERG25 and ERG24) were discarded due to their low quality (QMEAN $<-4)$.

Table 3. List of the 37 potential targets of compound $\mathbf{1 6}$ in C. krusei.

\begin{tabular}{|c|c|c|}
\hline UniProt Accession & ID $^{a}$ & Description \\
\hline A0A099P395 b & ALDH5 & Aldehyde dehydrogenase 5 , mitochondrial \\
\hline A0A2U9R6B5 ${ }^{b}$ & ALDH1 & Aldedh domain-containing protein \\
\hline A0A099P647 b & ALDH3 & Aldedh domain-containing protein \\
\hline A0A2U9R5Y1 b & ALDH2 & Aldedh domain-containing protein \\
\hline $\mathrm{A} 0 \mathrm{~A} 2 \mathrm{U} 9 \mathrm{R} 723^{\mathrm{b}}$ & ALDH4 & Aldedh domain-containing protein \\
\hline A0A099P843 ${ }^{\mathrm{b}}$ & MAPK1 & Mitogen-activated protein kinase CEK1 \\
\hline A0A099NVZ1 b & MAPK2 & Mitogen-activated protein kinase \\
\hline A0A1V2LG11 b & MAPK3 & Mitogen-activated protein kinase; uncharacterized protein HOG1 \\
\hline A0A1Z8JVT5 b & PK1 & Protein kinase domain-containing protein \\
\hline A0A2U9R7Y2 b & PK2 & Protein kinase domain-containing protein \\
\hline A0A099P0U0 ${ }^{b}$ & HDA1 & Histone deacetylase RPD3 \\
\hline A0A2U9RAK0 b & HDA2 & Histone deacetylase \\
\hline A0A1V2LMB8 ${ }^{b}$ & PPCTI-D & Peptidyl-prolyl cis-trans isomerase D \\
\hline A0A2U9QXT4 b & PPCTI1 & Peptidyl-prolyl cis-trans isomerase \\
\hline A0A099P2W3 b & РРСТI2 & Peptidyl-prolyl cis-trans isomerase \\
\hline A0A099P773 b & РРСТІ3 & Peptidyl-prolyl cis-trans isomerase \\
\hline A0A1Z8JS57 b & CA & Carbonic anhydrase \\
\hline A0A2U9RBI7 c & IDI1 & Isopentenyl-diphosphate Delta-isomerase \\
\hline A0A1Z8JJU5 ${ }^{c}$ & MVD & Diphosphomevalonate decarboxylase \\
\hline A0A2U9R9Y8 ${ }^{\mathrm{c}, \mathrm{d}}$ & ERG8 & Phosphomevalonate kinase \\
\hline A0A2U9R5L9 ${ }^{c}$ & ERG12 & Mevalonate kinase \\
\hline A0A2U9R6J $4^{c}$ & HMG1 & 3-hydroxy-3-methylglutaryl coenzyme A reductase \\
\hline A0A099P154 ${ }^{\mathrm{c}}$ & ERG13 & 3-hydroxy-3-methylglutaryl coenzyme A synthase \\
\hline A0A099P5C0 ${ }^{c}$ & ERG10 & Acetyl-CoA C-acetyltransferase IA \\
\hline A0A099P078 c,d & ERG26 & Sterol-4-alpha-carboxylate 3-dehydrogenase \\
\hline A0A1Z8JS11 ${ }^{\mathrm{c}, \mathrm{d}}$ & ERG27 & 3-keto-steroid reductase \\
\hline
\end{tabular}


Table 3. Cont.

\begin{tabular}{|c|c|c|}
\hline UniProt Accession & ID $^{a}$ & Description \\
\hline A0A2U9RAJ8 c,d & ERG4 & $\operatorname{Delta}(24(24(1)))$-sterol reductase \\
\hline A0A099P3X9 c,d & ERG5 & C-22 sterol desaturase \\
\hline A0A099P0V3 c,d & ERG3 & C-5 sterol desaturase \\
\hline A0A2U9QYN8 ${ }^{\mathrm{c}}$ & ERG2 & C-8 sterol isomerase \\
\hline A0A1V2LUI2 ${ }^{c}$ & ERG6 & Sterol 24-C-methyltransferase \\
\hline A0A099NZM6 c,d & ERG25 & Methylsterol monooxygenase \\
\hline A0A099P4I0 c,d & ERG24 & Delta(14)-sterol reductase \\
\hline A9YUC7 $\mathrm{c}$ & ERG11 & Lanosterol 14-alpha demethylase \\
\hline A0A2U9R113 ${ }^{c}$ & ERG9 & Squalene synthase \\
\hline A0A2U9R171 ${ }^{\mathrm{c}}$ & ERG7 & Lanosterol synthase \\
\hline A0A099NX62 ${ }^{c}$ & ERG1 & Squalene monooxygenase \\
\hline A0A099P5M1 ${ }^{\mathrm{c}}$ & ERG20 & (2E,6E)-farnesyl diphosphate synthase \\
\hline
\end{tabular}

a ID used along the manuscript for each target; ${ }^{\mathrm{b}}$ Identified by the target fishing approach; ${ }^{\mathrm{c}}$ Part of the ergosterol synthesis pathway; ${ }^{\mathrm{d}}$ Homology model discarded due to low quality.

Compound 16 was docked to the 30 proteins for which valid homology models could be generated, and the results of this step are presented as Supplementary Materials in Table S2. No docking solution could be found for ERG1; thus, 29 possible targets for the compound were further analyzed. The complexes predicted for these 29 proteins had the ligand within the binding cavity, showing interactions with functionally relevant residues. In addition, for seven out of twenty-nine proteins, only one valid pose of compound $\mathbf{1 6}$ was identified, while more than one ligand conformer was selected for the rest of the targets. In total, 67 potential ligand-receptor complexes were selected for additional analyses.

Molecular docking algorithms are designed for processing large amounts of compounds in a reasonable time. This processing speed comes at the cost of either neglecting or simplifying several factors involved in molecular recognition. Because of this, it is recommended that the post-processing of docking predicted complexes employ more accurate modeling methods. In this sense, the estimation of the free energies of binding from MD simulations had been proposed as a strategy for the refinement of the results obtained with molecular docking [31,39]. Hence, instead of analyzing the most probable targets of compound $\mathbf{1 6}$ from the results of the molecular docking calculations, MD simulations were performed and the free energies of binding were predicted, as described in the Materials and Methods section.

The simulations lead to $1.34 \mu \mathrm{s}$ of total simulation time across all predicted complexes, and the most stable conformation of compound $\mathbf{1 6}$ to each target was selected as that with the lowest value of predicted $\Delta \mathrm{G}$ of binding. The detailed results of the MMPBSA calculations are provided as Supplementary Materials in Table S3 and summarized in Figure 1.

According to the predicted free energies of binding, the most probable targets of compound 16 in C. krusei are ALDH1, MAPK3, PPCTI2, ALDH4 and PPCTI-D. Previous studies showed that amides derived from vanillic acid (highly similar to the compounds studied herein) interfere with the synthesis of ergosterol in C. guilliermondii [40]. Among the targets belonging to the ergosterol synthesis pathway, the firsts in the ranked list are ERG13, ERG11 and ERG9 at positions 8, 9 and 10, respectively. Despite these positions, negative values of $\Delta \mathrm{G}$ of binding are predicted for the later proteins, which indicates the possibility of binding the ligand to them.

Based on the modeling results, the binding modes of compound 16 to the top three target candidates ALDH1, MAPK3 and PPCTI2, as well as to the best-ranked proteins from the ergosterol synthesis pathway (ERG13, ERG11 and ERG9), were analyzed in detail. Figure 2 summarizes the predicted binding mode of the ligand to ALDH1, MAPK3 and PPCTI2, as well as the diagrams of the compound 16-receptor interactions. To select the structure for representation purposes, the $100 \mathrm{MD}$ snapshots used for MM-PBSA calculations were clustered, and the centroid of the most populated cluster was chosen 
as the representative structure. Only receptor residues interacting with the ligand in more than $50 \%$ of the analyzed snapshots are labeled and represented in the diagrams of interactions. The figures of the complexes were produced with UCSF Chimera [41], the frequencies of ligand-receptor interactions were analyzed with the aforementioned software and Cytoscape [42] and the interaction diagrams were obtained with Ligplot+ [43].

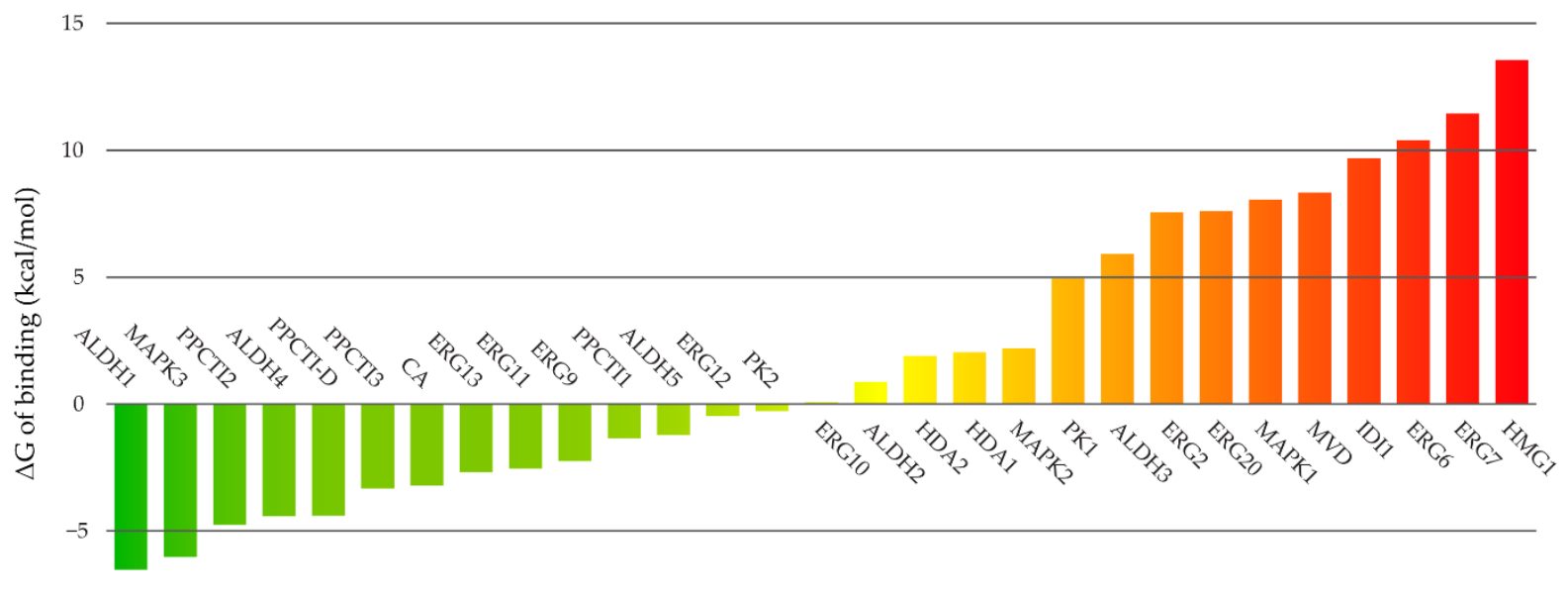

Figure 1. Predicted free energies of binding of compound 16 to its potential targets.

Compound 16 is predicted to bind to ALDH1 by blocking the access of the substrates to the catalytic residues and the cofactor. Its di-tert-butylphenol moiety orientates toward the bottom of the binding cavity, a mostly hydrophobic region lined by L143, L192, M193, W196, E286, L448, W473, F480 and F486. In addition, this substituent is favorably placed for $\pi-\pi$ stacking with F480. The carbonyl oxygen is predicted to accept a hydrogen bond from the side chain amine of C321 in $86 \%$ of the analyzed MD snapshots. The amide nitrogen of compound 16 is oriented to interact with $\mathrm{N} 478$, and it is observed to occasionally ( $16 \%$ of the snapshots) donate a hydrogen bond to the side chain of this residue. Finally, the chloro-benzene substituent occupies the entrance of the binding cavity, mainly interacting with F139, F189 and V319.

In the predicted complex with MAPK3, the amide nitrogen of compound 16 serves as a hydrogen bond donor to the side chain of E70, while the carbonyl oxygen accepts hydrogen bonds from the backbones of D162 and F163. The halogenated benzene ring occupies the entrance of the cavity, interacting with F34, R66, R69, L73 and D162. The other side of the compound is buried within the enzyme's active site and interacts with V37, K52, I83, C161, L165 and F163. This ring also positions favorably for stacking in front of F163.

The potential target of compound $\mathbf{1 6}$ ranked in the third position is PPCTI2. In this case, the ligand is predicted to bind at one end of the large substrate-binding groove. The di-tert-butylphenol substituent is predicted to be exposed to the solvent, with one of the tert-butyl moieties interacting with I54 and F57 and the aromatic ring contacting W118. The central linker of the compound makes contact with M58, W118 and L119, while the chlorine atom occupies a sub-pocket formed by R52, I54, M58, L59 and Q60. Additionally, the ligand's halogenated ring is located between I54, M58 and F110, with the possibility of stacking perpendicularly to the latter residue.

In Figure 3 are presented the predicted conformations of compound 16 bound to the ergosterol synthesis pathway enzymes ERG13, ERG11 and ERG9. The predicted ligand-ERG13 complex shows the compound filling the binding site of the CoA derivative substrates, with the chlorophenyl substituent occupying the bottom of it. The chlorine atom makes contact with C116, Y238 and H250, while the aromatic ring is accommodated in a hydrophobic region defined by Y211, P252, L256 and Y358. One hydrogen bond between the amide nitrogen of the ligand and the side chain of S207 stabilizes the complex in 55\% of 
the analyzed MD snapshots. In addition, the di-tert-butylphenol substituent is placed at the mouth of the cavity and interacts with Y150, T158, V202 and G204.
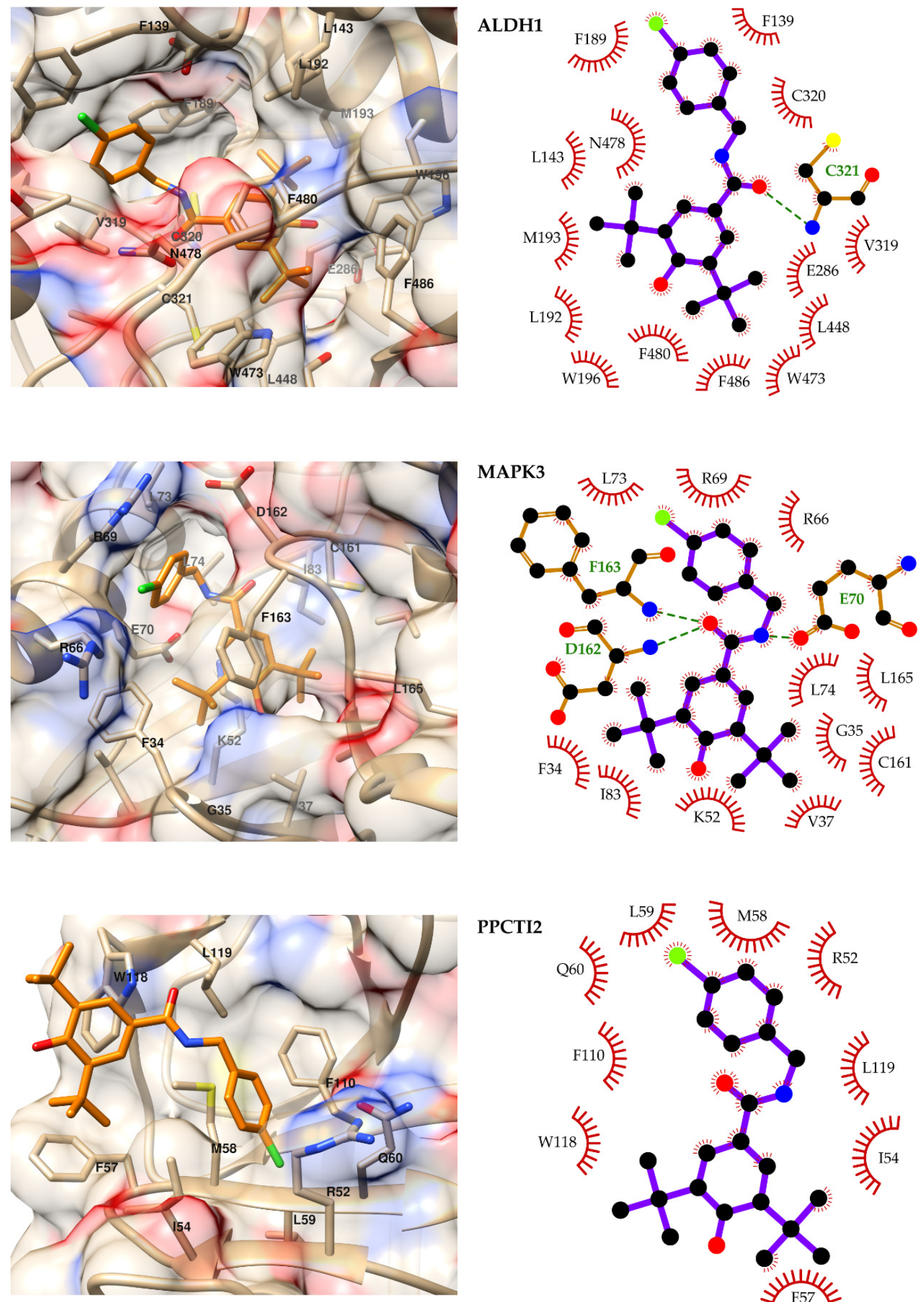

Figure 2. Predicted binding modes of compound 16 to ALDH1, MAPK3 and PPCTI2 (left) and diagrams of the predicted ligand-receptor interactions (right). For representing the predicted binding modes, compound $\mathbf{1 6}$ is depicted in orange, and the following scheme is used for non-carbon atoms: oxygen is red, nitrogen blue, chlorine green and sulfur yellow. In the interaction diagrams (left), carbon atoms are depicted in black, and heavy atoms are represented only for residues forming hydrogen bonds with the ligand. 

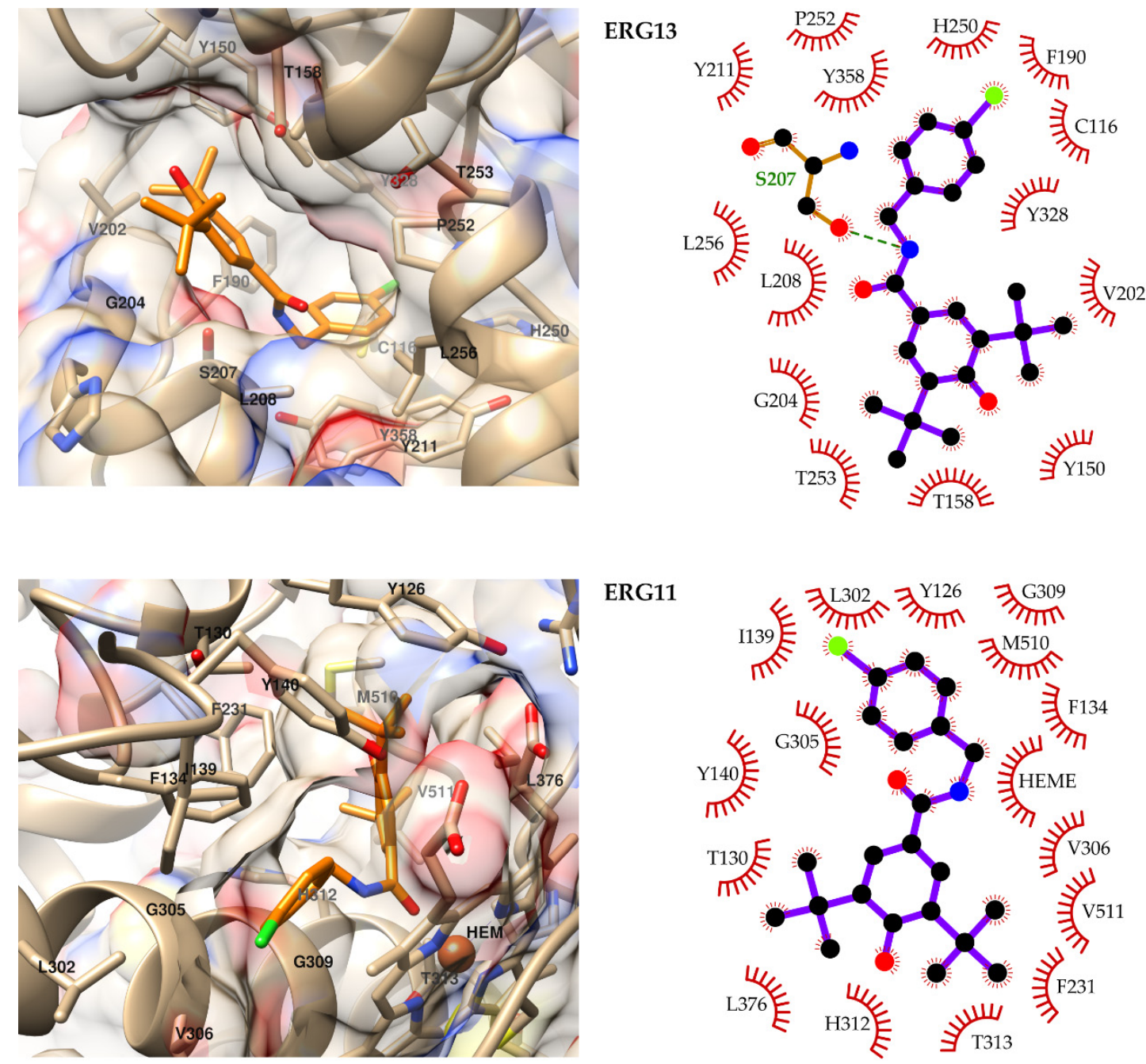

ERG11
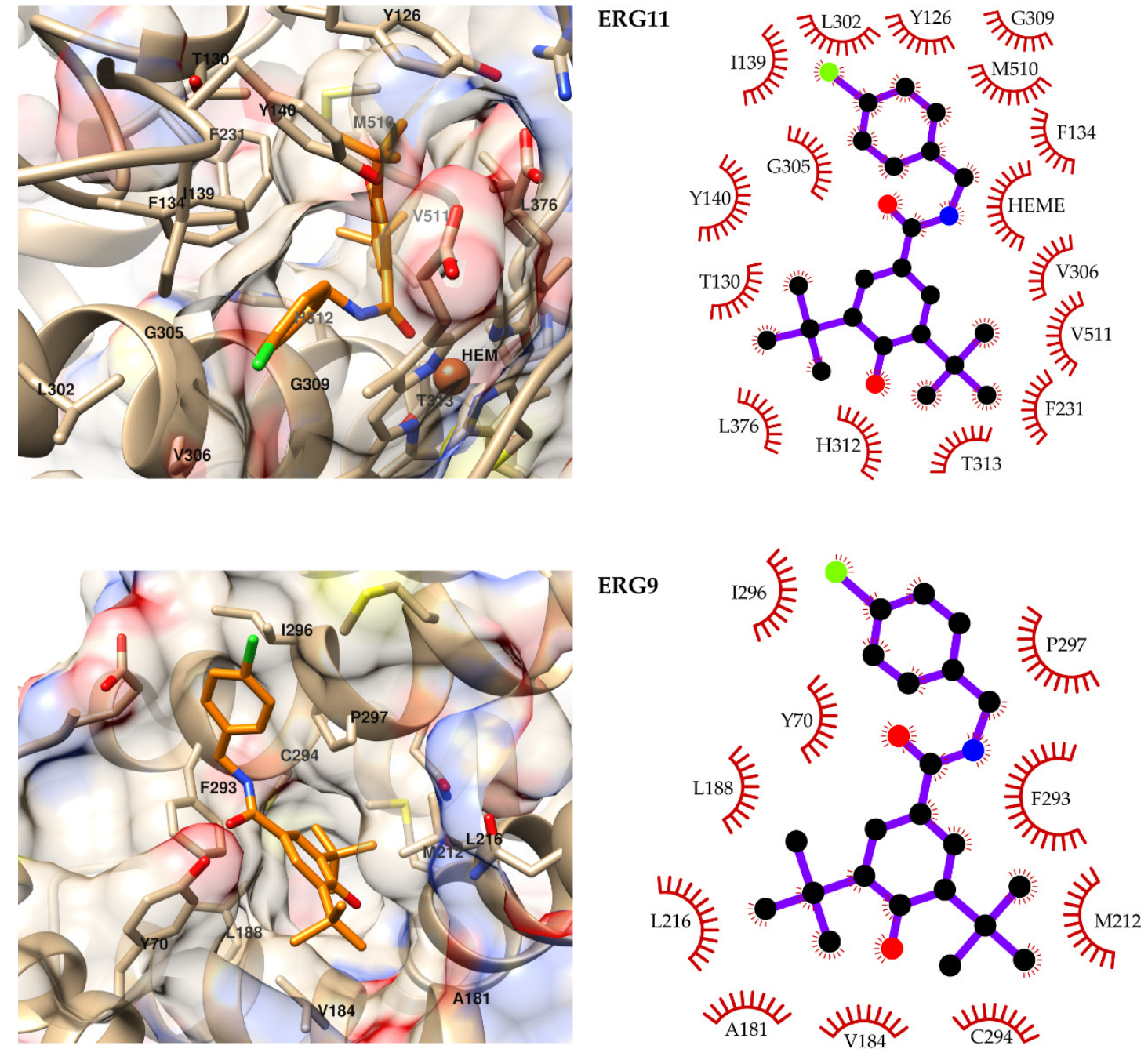

Figure 3. Predicted binding modes of compound 16 to ERG13, ERG11 and ERG9 (left) and diagrams of the predicted ligand-receptor interactions (right). For representing the predicted binding modes, the ligand is depicted in orange, and the following scheme is used for non-carbon atoms: oxygen is red, nitrogen blue, chlorine green and sulfur yellow. In the interaction diagrams (left), carbon atoms are depicted in black, and heavy atoms are represented only for residues forming hydrogen bonds with the ligand. 
The model obtained for ERG11 predicts the halogenated ring and the central linker of the compound facing the heme cofactor, with the carbonyl atom of the former contacting the $\mathrm{Fe}^{2+}$ ion of the latter. This aromatic moiety also interacts with F134, I139, G305, V306 and G309. The rest of the molecule forms a large network of interactions with Y126, T130, Y140, F231, H312, T313, L376, M510 and V511. Finally, the predicted complex of compound 16 with ERG9 is predicted to stabilize through Van der Waals and hydrophobic interactions. In this complex, the ligand's di-tert-butylphenol group occupies the bottom of the binding pocket and mainly interacts with M212, L216, F293 and C294. The central linker of the compound makes contact with Y70 and F293, while the halogenated ring is exposed to the solvent and only interacts with I296 and P297.

To get additional insight into the potential antifungal mechanism of action of this series of compounds and the influence of the substituents at positions R2, R3 and R4 (see Table 1), compounds $\mathbf{1 2 , 1 4}$ and $\mathbf{1 5}$ were subject to the same modeling strategy applied to 16. The predicted free energies of binding of these compounds to the ALDH1, MAPK3, PPCTI2, ERG13, ERG11 and ERG9 proteins are summarized in Figure 4 and provided as Supplementary Materials in Table S4. The results of these calculations show that compound 16 is the only one predicted with negative free energy of binding for all targets. Interestingly, compound 15 shows better a inhibition profile against ALDH1 than 16, while the same behavior is predicted for $\mathbf{1 2}$ and ERG11.

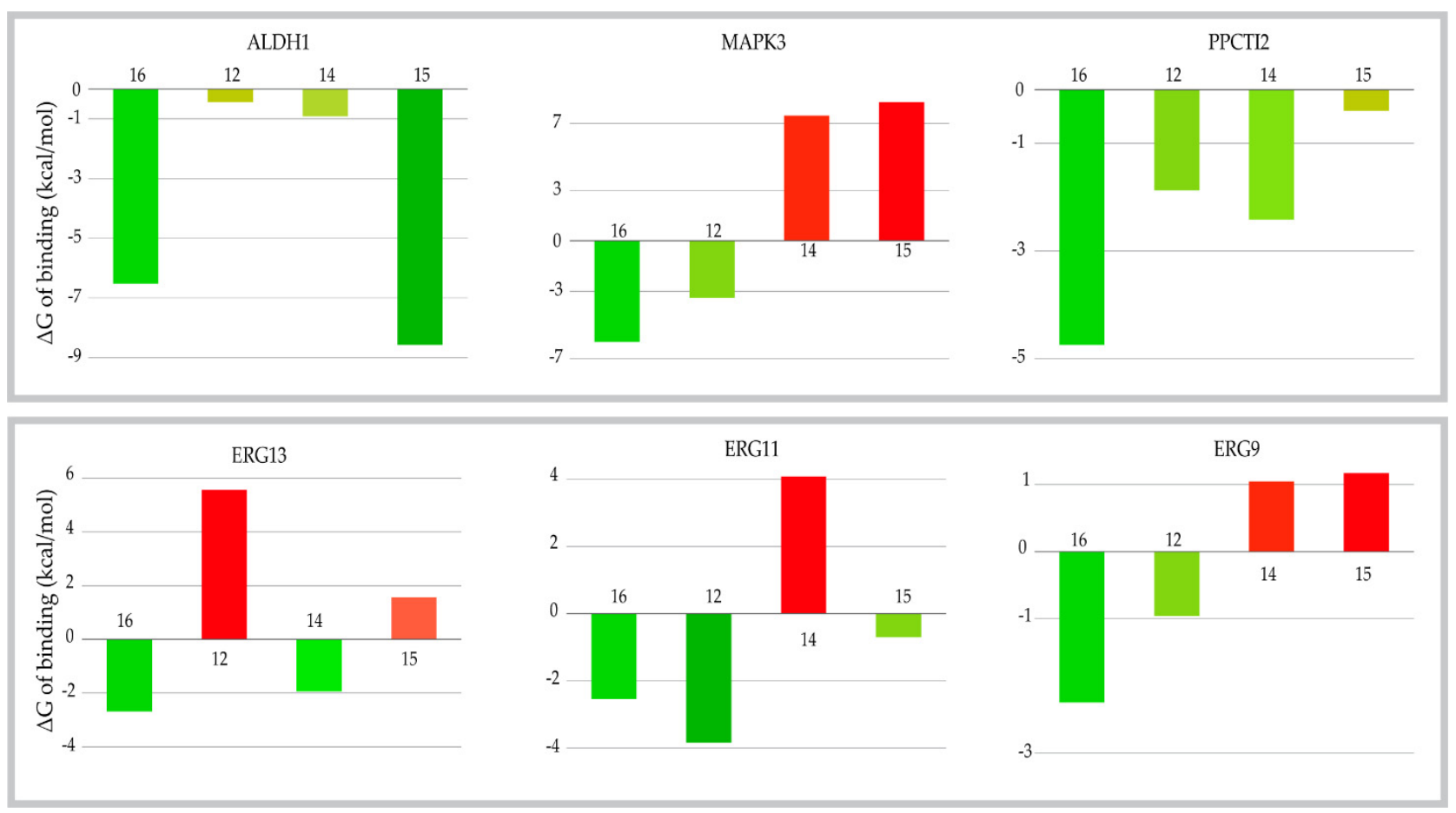

Figure 4. Predicted free energies of binding of compounds 12, 14 and 15 to ALDH1, MAPK3, PPCTI2, ERG13, ERG11 and ERG9.

The representative complexes predicted for compounds 12, 14, 15 and 16 with the most probable targets of the latter were analyzed in detail to better understand the results presented in Figure 4. All these complexes are provided in PDB format as Supplementary Materials in the file RepComplexes.zip. The improved free energy of binding of $\mathbf{1 5}$ relative to 16 in the complex with ALDH1 can be explained by the lack of tert-butyl moieties in the former. The lack of these groups makes the phenol substituent less bulky and allows compound 15 to occupy a deeper region of the binding pocket without losing the predicted hydrogen bond with C321. This movement positions the phenol group favorably for additional hydrogen bonding to the side chain of E286, thus increasing the stability of the ALDH1-15 complex. On the other hand, the absence of the tert-butyl and hydroxy 
substituents in $\mathbf{1 2}$ reduces the stability of the complex of this compound with ALDH1. For the predicted ALDH1-14 complex, the reduction in hydrophobicity and volume compared to compound 16, produced by the introduction of the methoxy substituents, might be responsible for the increase in the free energy of binding for this complex.

Despite the highly similar orientations of the four ligands in the complexes with MAPK3, there are large differences in their predicted free energies of binding. These can be explained by considering the energy components (see Table S4). The lowest Van der Waals component for compound 16 is related to its ability to better complement the receptor by pointing the bulky tert-butyl groups to sub-pockets delimited on each side by V54 and L151. In addition, the lack of a hydroxy group in compound $\mathbf{1 2}$ leads to a reduction (improvement) in the polar solvation energy component, suggesting that the presence of this group is unfavorable for ligand binding to MAPK3.

For the PPCTI2 target, the chloro-benzene moiety occupies the interior of the binding cavity while the substituted phenol ring is located at the entrance of the pocket, partially exposed to the solvent. This orientation of the compounds correlates with the fact that the main differences in the predicted free energies of binding are related to the Van der Waals contribution. For this reason, the substituted rings of compounds $\mathbf{1 4}$ and $\mathbf{1 6}$ are favored in terms of Van der Waals interactions and hence of total free energy of binding. This binding pattern with the chloro-benzene group occupying the bottom of the binding pocket is also observed for ERG13. In this case, ligand binding is predicted as being mainly driven by Van der Waals interactions as well, which favors the free energy of bonding of compounds 14 and 16. The worst performance in terms of binding energy to ERG13 is observed for compound 12, which is also affected by an increased electrostatic energy component due to the reduction of frequency of hydrogen bonding with S207.

For ERG11, the complexes with compounds 12, 14 and 15 show a binding pattern different from that predicted for 16. Interestingly, in these complexes, the amide group orients toward G309 and T313, which could explain the improved electrostatic energetic component relative to compound 16. The large Van der Waals contribution to the free energy of binding for compound $\mathbf{1 6}$ partially compensates for this gap in the electrostatic interactions, despite compound 12 being predicted to have the lowest free energy of binding to ERG11. Finally, binding to ERG13 also seems to be driven by Van der Waals interactions, as can be seen from Table S4.

\section{Discussion}

The therapeutic potential of halogenated derivatives as antifungal drugs was demonstrated in the present study via inhibitory action on fungal strains which are associated to human diseases. As shown, amides $\mathbf{2}$ and $\mathbf{1 4}$ were the most active compounds against the growth assay of C. parapsilosis, with an MIC of $31.25 \mu \mathrm{g} / \mathrm{mL}$. This pattern of substituents in the aromatic ring possibly contributes to the greater antifungal potency against this species. The amides $\mathbf{1 2}$ and $\mathbf{1 6}$ were bioactive against $C$. paropsilosis, with an MIC of $125 \mu \mathrm{g} / \mathrm{mL}$. However, considering an MIC of $250 \mu \mathrm{g} / \mathrm{mL}$, the two amides with para substituents, amides 9 and 15, had weak inhibitory action on the same strain.

The amide 16 stood out with the smallest MIC $(7.8 \mu \mathrm{g} / \mathrm{mL})$ against $C$. krusei ATCC 14243. This compound, with a bulky alkyl disubstitution in the meta position and a hydroxyl group in the para position, results in an effective inhibitor of fungal growth, even better than fluconazole, a drug used as standard. Compound $\mathbf{1 6}$ also showed bioactivity against eight different Candida strains with MICs ranging from 85.3-341.3 $\mu \mathrm{g} / \mathrm{mL}$. In fact, among these fungi used, five are clinical strains resistant to fluconazole. Interestingly, the MIC value against $C$. krusei ATCC $6258(85.3 \mathrm{mcg} / \mathrm{mL})$ was higher than that determined against C. krusei ATCC $14243(7.8 \mathrm{mcg} / \mathrm{mL})$. This strain was more sensitive to the inhibitory action of compound 16.

A new multi-resistant yeast, Candida auris, appeared in 2009 in East Asia and quickly spread around the world, being classified as a serious threat to public health due to infections with high transmissibility and mortality. Recently, epidemiological reports of 
C. auris outbreaks were released in the context of the COVID-19 pandemic [44], another very serious public health problem in the world [45]. In the present study, compound 16 showed antifungal activity against $C$. auris $01256 \mathrm{P}$ CDC, with an MIC of $85.3 \mu \mathrm{g} / \mathrm{mL}$. Therefore, this compound can be used as a prototype to obtain synthetic analogues with a better antifungal profile against $C$. auris.

Amide $\mathbf{1 4}$ was the second most potent compound in the growth assay of $C$. krusei, with an MIC of $31.25 \mu \mathrm{g} / \mathrm{mL}$, similar to the inhibition concentration achieved against C. parapsilosis. This amide was the substance that presented the highest inhibitory potency against both species of fungi, therefore having the best spectrum of antifungal action. Compounds 2, 9, 12 and 15 were also bioactive against both species, but at higher concentrations.

A triple substitution on the aromatic ring, one of them being a hydroxyl group in the para position and two lipophilic substituents in the meta position, is a hypothetical model for the antifungal activity of the synthetized amides against the tested yeasts. This pattern of activity is demonstrated by the inhibitory action of the trisubstituted compounds on the aromatic ring, for example, amides 9, 14 and 16. Compound 11 is trisubstituted, but with methoxyl at the para position instead of hydroxyl, and it was inactive. Interestingly, amide 14 was more potent than its analogue $\mathbf{9}$, suggesting that the presence of the spacer between the carbonyl group and the trisubstituted aromatic ring results in lower inhibitory potency against both Candida species. These findings agree with literature reports, such as the activity of syringic acid (MIC $=50 \mu \mathrm{g} / \mathrm{mL}$ ) against Candida albicans [46], the precursor of derivative 14 (MIC of $31.25 \mu \mathrm{g} / \mathrm{mL}$ ), and other benzamides also bioactive against species of this genus of fungi [40].

Furthermore, according to the classification scheme established by Alves et al. [47] for the antifungal potency of synthetic molecules against Candida species, MIC $<3.515 \mu \mathrm{g} / \mathrm{mL}$ indicates very strong bioactivity; $3.516-25 \mu \mathrm{g} / \mathrm{mL}$ strong bioactivity; $26-100 \mu \mathrm{g} / \mathrm{mL}$ moderate bioactivity; $101-500 \mu \mathrm{g} / \mathrm{mL}$ weak bioactivity; 500-2000 $\mu \mathrm{g} / \mathrm{mL}$ very weak bioactivity and $>2000 \mu \mathrm{g} / \mathrm{mL}$ no bioactivity. Compounds 2, 9, 12, 14, 15 and 16 showed a bioactivity profile ranging from weak to strong. Compound $\mathbf{1 6}$ showed weak bioactivity against C. parapsilosis and strong bioactivity against C. krusei ATCC 14243, while compound 14 exhibited moderate activity against both Candida species.

The modeling studies performed with compound 16 point to a multi-target mechanism of action. According to our calculations, the most probable targets of compound $\mathbf{1 6}$ in C. krusei relate to the redox balance in the cell (ALDH1), signaling pathways (MAPK3) and protein synthesis (PPCTI2). Among the proteins related to ergosterol biosynthesis, ERG13, ERG11 and ERG9 are also predicted as potential binders of this compound. Notably, the multi-target mechanism of action of compound 16 is supported by the predictions made for compounds 12, 14 and 15. Among these, 16 is the only one predicted with favorable free energies of binding to all targets.

Regarding the antifungal activity of derivative 16 against $C$. parapsilosis, the proposed targets of the compounds are highly conserved relative to C. krusei. Specifically, the residues directly interacting with the modeled ligand are conserved in both species, except for the F139G and Y140F mutations in ALDH1 and ERG11, respectively. Despite the high sequence conservation suggesting the potential inhibition of the targets from both species, this remains to be determined in future works.

When analyzing the obtained results, it must be considered that the biological assays performed focus on the antifungal activity. This is a complex endpoint that should not be solely correlated with enzymes' inhibition. Other factors such as diverse detoxification mechanisms and membrane permeability to the compounds can lead to differential susceptibility to antifungal agents.

Aldehyde dehydrogenases, such as ALDH1 and ALDH4, are present in a wide range of species and relate to the cellular response to oxidative stress in the cell [48]. Thus, the predicted interaction of compound $\mathbf{1 6}$ with these targets might lead to a redox imbalance in the fungus. PPCTI2 belongs to the peptidyl prolyl cis-trans isomerases family of proteins, catalyzing the isomerization of the peptide bond preceding prolines within protein sub- 
strates [49]. Despite this family of proteins having not been fully characterized in Candida species, some of its members have been proposed as targets capable of overcoming drug resistance in C. albicans [50,51].

The three selected potential targets related to ergosterol synthesis are essential for the growth and virulence of $C$. albicans [52], and this particular pathway has been widely exploited for drug development. Finally, MAPK3 (Hog1 mitogen-activated protein kinase) has been extensively investigated in C. albicans and proposed by different researchers as an attractive target for the development of new antifungal agents [53-55]. Interestingly, this protein kinase has been established as essential for the response to oxidative stress in C. albicans [56]. We hypothesize that the simultaneous binding of compound $\mathbf{1 6}$ to aldehyde dehydrogenase enzymes and to MAPK3 could lead to a synergic effect compromising the ability of the microorganism to respond to oxidative stress.

Most information reported in the literature establishes $C$. albicans as the model organism to study the mechanism of action of antifungal drugs in Candida species. Hence, the proposed mechanism of action of compound 16 in C. krusei ATCC 14243 can only be supposed based on the available information. Nevertheless, we consider that the modeling studies performed in this research can guide future experimental efforts toward the prioritization of experiments for the clarification of the mechanism of action of the assayed amide derivatives.

\section{Materials and Methods}

\subsection{General Information}

Purification of the compounds was performed by column chromatography on silica gel 60 (ART. 7734 Merck, St. Louis, MO, USA) using a hexane: ethyl acetate (Hex:EtOAc) solvent gradient and confirmed by analytical thin-layer chromatography on silica gel $60 \mathrm{~F}_{254}$, using ultraviolet light at two wavelengths $(254$ and $366 \mathrm{~nm}$ ) from a Mineralight apparatus (UVP, Upland, CA, USA) or $\mathrm{H}_{2} \mathrm{SO}_{4}$ in $5 \%$ ethanol for detection. FTIR spectra were recorded in a Prestige-21 FTIR spectrometer (Shimadzu, Kyoto, Japan) using $\mathrm{KBr}$ pellets. ${ }^{1} \mathrm{H}$ - and ${ }^{13} \mathrm{C}$-nuclear magnetic resonance (NMR) spectra were obtained on a MERCURY machine (200 and $50 \mathrm{MHz}$ for ${ }^{1} \mathrm{H}$ and ${ }^{13} \mathrm{C}$, respectively). Varian (Palo Alto, CA, USA) in deuterated solvents $\left(\mathrm{CDCl}_{3}, \mathrm{MeOD}\right.$ or DMSO-d6 $)$ and tetramethylsilane (TMS) was used for the internal standard. Chemical shifts were measured in parts per million (ppm) and coupling constants $(J)$ in Hz. Measurements of atomic mass for the compounds was carried out using an Ultraflex II TOF/TOF mass spectrometer (Bruker Daltonik GmbH, Bremen, Germany) equipped with a high-performance solid-state laser $(\lambda=355 \mathrm{~nm})$ and reflector. The system was operated by the Bruker Daltonik FlexControl 2.4 software package (Bruker, Bremen, Germany). All spectroscopic data are available [35].

\subsection{General Preparation of $N-(4-H a l o b e n z y l) a m i d e s$}

The compounds 1-20 (Figure 5) were prepared by this procedure: in a $100 \mathrm{~mL}$ flask equipped with magnetic stirring, the organic acid $(1.35 \mathrm{mmol}, 200 \mathrm{mg})$ was dissolved in dimethylformamide (DMF, $2.7 \mathrm{~mL})$ and trimethylamine $(0.14 \mathrm{~mL}, 1.35 \mathrm{mmol})$. The solution was cooled in an ice bath $\left(0^{\circ} \mathrm{C}\right)$. Then, 4 -halobenzylamine $(1.35 \mathrm{mmol})$ was added. Soon after, a solution of BOP $(1.35 \mathrm{mmol})$ in $\mathrm{CH}_{2} \mathrm{Cl}_{2}(10 \mathrm{~mL})$ was added to the flask. The reaction was stirred at $0{ }^{\circ} \mathrm{C}$ for $30 \mathrm{~min}$ and then for an additional period at room temperature for $2 \mathrm{~h}$. After the reaction, the $\mathrm{CH}_{2} \mathrm{Cl}_{2}$ was removed under reduced pressure, and the solution was poured into a separatory funnel containing water $(10 \mathrm{~mL})$ and EtOAc $(10 \mathrm{~mL})$. The product was extracted with EtOAc $(3 \times 10 \mathrm{~mL})$. The organic phase was washed sequentially with $1 \mathrm{~N} \mathrm{HCl}$, water, $1 \mathrm{M} \mathrm{NaHCO}_{3}$ and water $(10 \mathrm{~mL}$ of each); it was then dried with $\mathrm{Na}_{2} \mathrm{SO}_{4}$, filtered and concentrated in a rotary evaporator. The amide was purified by gel chromatography on a silica gel column using an EtOAc:Hex mixture gradient of increasing polarity as the mobile phase [21,35]. 
<smiles>COc1cc(/C=C/C(=O)NCc2ccc(Cl)cc2)ccc1O</smiles><smiles>COc1ccc(/C=C/C(=O)NCc2ccc(Cl)cc2)cc1</smiles><smiles>O=C(/C=C/c1ccc(O)cc1)NCc1ccc(Cl)cc1</smiles><smiles>O=C(/C=C/c1ccc(Cl)cc1)NCc1ccc(Cl)cc1</smiles><smiles>COc1cc(/C=C/C(=O)NCc2ccc(Cl)cc2)cc(OC)c1O</smiles><smiles>O=C(/C=C/c1ccccc1[N+](=O)[O-])NCc1ccc(Cl)cc1</smiles><smiles>COc1cc(/C=C/C(=O)NCc2ccc(Cl)cc2)cc(OC)c1OC</smiles><smiles>O=C(NCc1ccc(Cl)cc1)c1ccccc1</smiles><smiles>O=C(NCc1ccc(Cl)cc1)c1ccc(-c2ccccc2)cc1</smiles><smiles>COc1cc(C(=O)NCc2ccc(Cl)cc2)cc(OC)c1O</smiles><smiles>O=C(NCc1ccc(Cl)cc1)c1ccc(O)cc1</smiles><smiles>CC(C)(C)c1cc(C(=O)NCc2ccc(Cl)cc2)cc(C(C)(C)C)c1O</smiles><smiles>COc1ccc(O)c(C(=O)NCc2ccc(Cl)cc2)c1</smiles><smiles>COc1cc(C(=O)NCc2ccc(F)cc2)ccc1O</smiles><smiles>COc1cc(C(=O)NCc2ccc(Br)cc2)ccc1O</smiles><smiles>Cc1cc(C(=O)NCc2ccc(Cl)cc2)ccc1[N+](=O)[O-]</smiles>

Figure 5. Halogenated amides synthetized via BOP.

\subsection{Evaluation of Antimicrobial Activity}

4.3.1. Microbiological Strains and Culture Medium

The microorganisms used in the microbiological tests were strains of Candida parapsilosis (ATCC 22019) and Candida krusei (ATCC 14243). The culture medium used in the antifungal activity assays was Sabouraud agar dextrose prepared from an initial inoculum suspension according to the $0.5 \mathrm{McF}$ arland scale. Medium was prepared according to the manufacturer's instructions.

\subsubsection{Determination of the Minimum Inhibitory Concentration (MIC)}

The broth microdilution (BMD) antifungal susceptibility test was performed according to M27-A3 protocol using RPMI broth ( $\mathrm{pH} 7.0$ ) buffered with 0.165 M MOPS [3-(N-morpholino)propanesulfonic acid (Sigma-Aldrich, St Louis, MO, USA) [57]. Compounds were dissolved in dimethyl sulfoxide (DMSO; Sigma-Aldrich) and tested at concentrations ranging from 1.95 to $1000 \mu \mathrm{g} / \mathrm{mL}$. The yeasts and compounds were incubated in 96-well culture plates at $35^{\circ} \mathrm{C}$ for $24 \mathrm{~h}$, and the results were examined visually. The 
minimum inhibitory concentration (MIC) of each compound was determined as the concentration that inhibited $50 \%$ of fungal growth [58].

\subsection{Evaluation of Antimicrobial Activity Compound 16}

\subsubsection{Microbiological Strains and Culture Medium}

Eight strains were used for this test: Candida parapsilosis ATCC 22019, C. krusei ATCC 6258, C. auris 01256P derived from CDC B11903 and five clinical strains resistant to fluconazole, including two C. albicans, one C. parapsilosis, one C. tropicalis and one C. glabrata. All microorganisms used belong to the Laboratory of Bioprospection in Antimicrobial Molecules (LABIMAN) from Federal University of Ceará. These were seeded on Sabouraud dextrose agar and incubated at $35^{\circ} \mathrm{C}$ for $24 \mathrm{~h}$.

\subsubsection{Determination of the Minimum Inhibitory Concentration (MIC)}

The broth microdilution technique was performed according to document M27-A3 (CLSI, 2008) using RPMI 1640 culture medium (pH $7.0 \pm 0.1$ ) buffered with $0.165 \mathrm{M}$ morpholinopropanesulfonic acid (MOPS) (Sigma, St. Louis, MO, USA).

From a 24-h cultivation of the yeasts, carried out in potato agar added with chloramphenicol, an initial inoculum suspension was prepared according to the $0.5 \mathrm{McF}$ arland scale. Then, dilutions were made in RPMI 1640 medium to obtain a final inoculum containing 0.5 to $2.5 \times 10^{3} \mathrm{CFU} / \mathrm{mL}$, which was added to the plate. The microplates containing the inoculum and the drug were incubated at $35^{\circ} \mathrm{C}\left( \pm 2{ }^{\circ} \mathrm{C}\right)$ for $24 \mathrm{~h}$. Readings were taken visually. Compound 16 was tested in concentrations ranging from 1024 to $2 \mu \mathrm{g} / \mathrm{mL}$.

\subsection{Computational Methods}

\subsubsection{Molecular Modeling}

Molecular modeling was based on our previous studies focusing on the proposal of potential mechanisms of action for bioactive compounds [33,59,60]. Potential targets of compound $\mathbf{1 6}$ in C. krusei were identified by combining computational target fishing and previous bioactivity data obtained for similar compounds against C. guilliermondii [40]. Specifically, in [40], it was reported that this type of compound interferes with the synthesis of ergosterol in C. guilliermondii. Afterward, molecular docking of compound $\mathbf{1 6}$ was performed against all its potential targets in C. krusei. Next, molecular dynamics (MD) simulations were performed for the predicted complexes, and the free energies of binding were computed by means of the molecular mechanics combined with the PoissonBoltzmann and surface area (MM-PBSA) method. The most probable targets of compound 16 in C. krusei were finally proposed according to the results of the estimated free energies of binding.

\subsubsection{Targets Selection}

Compound 16 was used as query on the Similarity Ensemble Approach (SEA) web server [61] for the identification of its possible targets. Computational target fishing approaches rely on the ligand-receptor interaction data available on different databases, with this data being biased against human proteins. Because of this, a homology-based approach was implemented to identify proteins in C. krusei homologs to those identified during the target fishing stage. For this, the sequences of the identified targets were subject to a BLAST [62] search against the C. krusei (taxid 4909) proteins in the Reference Sequence proteins (refseq_protein) database using the NCBI BLAST web server implementation (https: / /blast.ncbi.nlm.nih.gov/, accessed on 4 June 2020). C. krusei proteins covered on at least $70 \%$ of its length by the BLAST alignment and identical to the query sequence on at least $40 \%$ were selected as potential targets of compound $\mathbf{1 6}$.

In addition, some amides derived from vanillic acid highly similar to the compounds studied herein have been demonstrated to interfere with the synthesis of ergosterol in C. guilliermondii [40]. Despite the fact that no protein related to ergosterol synthesis was identified in the above step as a potential target for compound 16, the enzymes involved in 
this metabolic pathway were included in our investigation. These were defined from the Candida Genome Database [63] (Pathway PWY3B3-3). Considering that the metabolic pathways in this database are defined for C. albicans, the homologous proteins were identified in C. krusei through a BLAST search.

\subsubsection{Molecular Docking}

The molecular docking protocol applied in this research has been described elsewhere $[60,64]$. In brief, the initial three-dimensional structure of compound $\mathbf{1 6}$ was generated with OpenEye's Omega [65,66], and am1-bcc partial atomic charges were added to it with Molcharge [67]. Since the structures of the investigated proteins from C. krusei are unavailable, homology models were generated for them with the SWISSMODEL server [68].

Docking calculations were performed with the GOLD software [69]. The receptors' binding sites were defined from the ligands present on the templates used for the homology modeling. Primary docking took place with the ChemPLP scoring function, and 30 different poses of compound $\mathbf{1 6}$ were explored for each target with the search efficiency parameter set to $200 \%$. Additionally, the side chains of the residues pointing toward the binding cavity were set as flexible. The predicted binding poses were rescored with the GoldScore, ChemScore and ASP scoring functions of GOLD. A consensus scoring approach was applied to select the most probable binding modes of the ligand to the explored receptors, as described in our previous publications $[60,64]$.

\subsubsection{Molecular Dynamics Simulations and Prediction of the Free Energies of Binding}

The Amber 20 [70] package was used for MD simulations and the estimation of the free energies of binding. The gaff 2 and ff19SB force fields were employed to parametrize the ligand and proteins, respectively. $\mathrm{Zn}^{2+}$ ions were parametrized according to the cationic dummy atom model proposed by [71]. The parameters for the NAD and Heme cofactors were taken from the contributed files provided with the Amber 20 distribution [72,73]. All the simulations were run in explicit solvent, following the same energy minimization, heating, equilibration and production steps for all systems.

Complexes (receptor + ligand) were enclosed in truncated octahedron boxes, solvated with OPC water molecules and neutralized with either $\mathrm{Na}^{+}$or $\mathrm{Cl}^{-}$counterions. The solvated systems were sequentially energy-minimized, heated from $0 \mathrm{~K}$ to $300 \mathrm{~K}$ and equilibrated as previously described $[60,64]$. Every equilibrated system was used as input to five production runs of 4-ns length each. The initial velocities were randomly initialized before each production run. This procedure yielded a total of $20 \mathrm{~ns}$ simulation time per complex.

The free energies of binding of compound $\mathbf{1 6}$ to its potential targets were computed using the MM-PBSA method as implemented in the MM-PBSA.py script of Amber 20. Calculations took place across $100 \mathrm{MD}$ snapshots evenly extracted from the five production runs. Snapshots extraction started at $1 \mathrm{~ns}$ and continued until the last one for each production run. The ionic strength for MM-PBSA calculations was set to $100 \mathrm{mM}$.

\section{Conclusions}

The twenty evaluated derivatives resulted in the identification of various antifungal substances with promising MIC values (341.3 to $7.8 \mu \mathrm{g} / \mathrm{mL}$ ). Among the bioactive compounds $(2,9,12,14,15$ and 16), amide 16 was the most potent one against Candida krusei ATCC 14243, with better antifungal activity than the standard drug fluconazole. Comparative analysis of the bioactive compounds suggests that trisubstituted amides with the oxyalkyl or bulk alkyl substituents in meta positions and a hydroxyl group in the para position have better antifungal activity against Candida strains. A computational investigation of the potential mechanism of action of compound 16 in C. krusei revealed a possible multi-target mechanism of action involving different cellular processes. These are mainly related to the redox balance in the cell, kinase signaling pathways, protein synthesis 
and ergosterol synthesis. The data of the present study reveal potent bioactive substances with potential applications in the development of new candidates for antifungal drugs.

Supplementary Materials: The following are available online at https:/ /www.mdpi.com/article/10 .3390/ijms23010419/s1.

Author Contributions: Investigation, methodology and writing-original draft preparation, Y.P.-C., R.C.M. and A.B.S.D.; methodology, C.R.d.S., J.B.d.A.N. and C.d.S.D.; writing-review, H.V.N.J.; data curation, writing-review and editing and supervision, D.P.d.S. All authors have read and agreed to the published version of the manuscript.

Funding: This research was funded by the Brazilian agencies Conselho Nacional de Desenvolvimento Científico e Tecnológico (CNPq) (grant number: 306661/2016-0) and Coordenação de Aperfeiçoamento de Pessoal de Nível Superior (CAPES).

Informed Consent Statement: Not applicable.

Data Availability Statement: The data presented in this study are available in the article and associated supplementary material and in https://repositorio.ufpb.br/jspui/handle/tede/8806.

Acknowledgments: This work was supported by the Brazilian agencies Conselho Nacional de Desenvolvimento Científico e Tecnológico (CNPq) and Coordenação de Aperfeiçoamento de Pessoal de Nível Superior (CAPES).

Conflicts of Interest: No conflicts of interest are associated with this work.

\section{References}

1. Sardi, J.C.O.; Scorzoni, L.; Bernardi, T.; Fusco-Almeida, A.M.; Mendes Giannini, M.J.S. Candida species: Current epidemiology, pathogenicity, biofilm formation, natural antifungal products and new therapeutic options. J. Med. Microbiol. 2013, 62, 10-24. [CrossRef]

2. Ostrosky-Zeichner, L.; Kullberg, B.J.; Bow, E.J.; Hadley, S.; León, C.; Nucci, M.; Patterson, T.F.; Perfect, J.R. Early treatment of candidemia in adults: A review. Med. Mycol. 2011, 49, 113-120. [CrossRef]

3. Giri, S.; Kindo, A.J. A review of Candida species causing blood stream infection. Indian J. Med. Microbiol. 2012, 30, 270-278. [CrossRef] [PubMed]

4. Barbedo, L.S.; Sgarbi, D.B.G. Candidíase. DST J. Bras. Doenças Sex Transm. 2010, 22, 22-38.

5. Lima, T.C.; Ferreira, A.R.; Silva, D.F.; Lima, E.O.; de Sousa, D.P. Antifungal activity of cinnamic acid and benzoic acid esters against Candida albicans strains. Nat. Prod. Res. 2018, 32, 572-575. [CrossRef]

6. $\quad$ Lima, T.C.; Ferreira, A.R.; Barboza, J.N.; Filho, C.S.M.B.; Silva, D.F.; Lima, E.O.; de Sousa, D.P. Antimicrobial Activity of Cinnamic and Benzoic Methyl Esters. Lat. Am. J. Pharm. 2018, 37, 1011-1016.

7. Korošec, B.; Sova, M.; Turk, S.; Kraševec, N.; Novak, M.; Lah, L.; Stojan, J.; Podobnik, B.; Berne, S.; Zupanec, N.; et al. Antifungal activity of cinnamic acid derivatives involves inhibition of benzoate 4-hydroxylase (CYP53). J. Appl. Microbiol. 2014, 116, 955-966. [CrossRef]

8. Chhillar, R.; Dhingra, D. Antidepressant-like activity of gallic acid in mice subjected to unpredictable chronic mild stress. Fundam. Clin. Pharmacol. 2013, 27, 409-418. [CrossRef]

9. Dhingra, D.; Chhillar, R.; Gupta, A. Antianxiety-like activity of gallic acid in unstressed and stressed mice: Possible involvement of nitriergic system. Neurochem. Res. 2012, 37, 487-494. [CrossRef]

10. Kroes, B.H.; van den Berg, A.J.; van Ufford, H.C.Q.; van Dijk, H.; Labadie, R.P. Anti-inflammatory activity of gallic acid. Planta Med. 1992, 58, 499-504. [CrossRef]

11. Lorusso, L.; Mikhaylova, S.V.; Capelli, E.; Ferrari, D.; Ngonga, G.K.; Ricevuti, G. Immunological aspects of chronic fatigue syndrome. Autoimmun. Rev. 2009, 8, 287-291. [CrossRef]

12. Kim, K.D.; Song, M.H.; Yum, E.K.; Jeon, O.S.; Ju, Y.W.; Chang, M.S. Melanogenesis inhibition by mono-hydroxycinnamic ester derivatives in B16 melanoma cells. Bull. Korean Chem. Soc. 2010, 31, 181-184. [CrossRef]

13. Guzman, J.D. Natural cinnamic acids, synthetic derivatives and hybrids with antimicrobial activity. Molecules 2014, 19, 19292-19349. [CrossRef]

14. Ueda, S.; Okada, T.; Nagasawa, H. Oxindole synthesis by palladium-catalysed aromatic C-H alkenylation. Chem. Commun. 2010, 46, 2462-2464. [CrossRef]

15. Watson, A.J.; Maxwell, A.C.; Williams, J.M. Ruthenium-catalyzed oxidation of alcohols into amides. Org. Lett. 2009, 11, 2667-2670. [CrossRef]

16. Foo, S.W.; Oishi, S.; Saito, S. Aldol condensation of amides using phosphazene-based catalysis. Tetrahedron lett. 2012, 53, 5445-5448. [CrossRef]

17. Wu, J.W.; Wu, Y.D.; Dai, J.J.; Xu, H.J. Benzoic Acid-Catalyzed Transamidation Reactions of Carboxamides, Phthalimide, Ureas and Thioamide with Amines. Adv. Synth. Catal. 2014, 356, 2429-2436. [CrossRef] 
18. Shen, X.X.; Liu, Q.; Xing, R.G.; Zhou, B. Reduction of N-(alkoxy (aryl) methyl) benzamide Compounds by a Hantzsch Ester 1, 4-Dihydropyridine Using Pd/C as a Catalyst. Catal. Lett. 2008, 126, 361-366. [CrossRef]

19. Zhang, M.; Lu, X.; Zhang, H.J.; Li, N.; Xiao, Y.; Zhu, H.L.; Ye, Y.H. Synthesis, structure, and biological assay of cinnamic amides as potential EGFR kinase inhibitors. Med. Chem. Res. 2013, 22, 986-994. [CrossRef]

20. Nomura, E.; Kashiwada, A.; Hosoda, A.; Nakamura, K.; Morishita, H.; Tsuno, T.; Taniguchi, H. Synthesis of amide compounds of ferulic acid, and their stimulatory effects on insulin secretion in vitro. Bioorg. Med. Chem. 2003, 11, 3807-3813. [CrossRef]

21. Fu, J.; Cheng, K.; Zhang, Z.M.; Fang, R.Q.; Zhu, H.L. Synthesis, structure and structure-activity relationship analysis of caffeic acid amides as potential antimicrobials. Eur. J. Med. Chem. 2010, 45, 2638-2643. [CrossRef]

22. Waisser, K.; Pesina, M.; Holý, P.; Pour, M.; Bures, O.; Kunes, J.; Klimesová, V.; Buchta, V.; Kubanová, P.; Kaustová, J. Antimycobacterial and antifungal isosters of salicylamides. Arch. Pharm. 2003, 336, 322-335. [CrossRef]

23. Rognan, D. Structure-Based Approaches to Target Fishing and Ligand Profiling. Mol. Inform. 2010, 29, 176-187. [CrossRef]

24. Schomburg, K.T.; Rarey, M. What is the potential of structure-based target prediction methods? Future Med. Chem. 2014, 6, 1987-1999. [CrossRef]

25. Wang, C.; Kurgan, L. Survey of Similarity-Based Prediction of Drug-Protein Interactions. Curr. Med. Chem. 2020, 27, 5856-5886. [CrossRef]

26. Wang, C.; Kurgan, L. Review and comparative assessment of similarity-based methods for prediction of drug-protein interactions in the druggable human proteome. Brief Bioinform. 2019, 20, 2066-2087. [CrossRef]

27. Sydow, D.; Burggraaff, L.; Szengel, A.; van Vlijmen, H.W.T.; IJzerman, A.P.; van Westen, G.J.P.; Volkamer, A. Advances and Challenges in Computational Target Prediction. J. Chem. Inf. Model. 2019, 59, 1728-1742. [CrossRef]

28. Keiser, M.J.; Setola, V.; Irwin, J.J.; Laggner, C.; Abbas, A.I.; Hufeisen, S.J.; Jensen, N.H.; Kuijer, M.B.; Matos, R.C.; Tran, T.B.; et al. Predicting new molecular targets for known drugs. Nature 2009, 462, 175-181. [CrossRef]

29. Lounkine, E.; Keiser, M.J.; Whitebread, S.; Mikhailov, D.; Hamon, J.; Jenkins, J.L.; Lavan, P.; Weber, E.; Doak, A.K.; Côté, S.; et al. Large-scale prediction and testing of drug activity on side-effect targets. Nature 2012, 486, 361-367. [CrossRef]

30. Liu, B.; Fu, X.Q.; Li, T.; Su, T.; Guo, H.; Zhu, P.L.; Tse, A.K.; Liu, S.M.; Yu, Z.L. Computational and experimental prediction of molecules involved in the anti-melanoma action of berberine. J. Ethnopharmacol. 2017, 208, 225-235. [CrossRef]

31. Poli, G.; Granchi, C.; Rizzolio, F.; Tuccinardi, T. Application of MM-PBSA Methods in Virtual Screening. Molecules 2020, 25, 1971. [CrossRef]

32. Tutone, M.; Virzì, A.; Almerico, A.M. Reverse screening on indicaxanthin from Opuntia ficus-indica as natural chemoactive and chemopreventive agent. J. Theor. Biol. 2018, 455, 147-160. [CrossRef] [PubMed]

33. Turkez, H.; Nóbrega, F.R.D.; Ozdemir, O.; Filho, C.S.M.B.; Almeida, R.N.; Tejera, E.; Perez-Castillo, Y.; de Sousa, D.P. NFBTA: A Potent Cytotoxic Agent against Glioblastoma. Molecules 2019, 24, 2411. [CrossRef]

34. Montes, R.C.; de Freitas, T.S.; Costa, M.S.; Oliveira, F.S.; Campina, F.F.; Ferreira, A.R.; Ferreira, S.O.; Melo, H.D.; Dias, C.S.; de Sousa, D.P. Antimicrobial evaluation of cinnamic and benzoic haloamides. J. Chem. Pharm. Res. 2016, 8, 311-320.

35. Montes, R.C.; Perez, A.L.; Medeiros, C.I.; Araújo, M.O.; Lima, E.O.; Scotti, M.T.; de Sousa, D.P. Synthesis, Antifungal Evaluation and In Silico Study of N-(4-Halobenzyl)amides. Molecules 2016, 21, 1716. [CrossRef]

36. Joullié, M.M.; Lassen, K.M. Evolution of amide bond formation. Arkivoc 2010, 8, 189-250. [CrossRef]

37. Montalbetti, C.A.; Falque, V. Amide bond formation and peptide coupling. Tetrahedron 2005, 61, 10827-10852. [CrossRef]

38. Malz, F.; Jancke, H. Validation of quantitative NMR. J. Pharm. Biomed. Anal. 2005, 38, 813-823. [CrossRef]

39. Rastelli, G.; Pinzi, L. Refinement and Rescoring of Virtual Screening Results. Front. Chem. 2019, 7, 498. [CrossRef]

40. Santos Oliveira, A.J.M.; de Castro, R.D.; Pessôa, H.L.F.; Wadood, A.; de Sousa, D.P. Amides Derived from Vanillic Acid: Coupling Reactions, Antimicrobial Evaluation, and Molecular Docking. Biomed. Res. Int. 2019, 2019, 9209676. [CrossRef]

41. Pettersen, E.F.; Goddard, T.D.; Huang, C.C.; Couch, G.S.; Greenblatt, D.M.; Meng, E.C.; Ferrin, T.E. UCSF Chimera-A visualization system for exploratory research and analysis. J. Comput. Chem. 2004, 25, 1605-1612. [CrossRef]

42. Shannon, P.; Markiel, A.; Ozier, O.; Baliga, N.S.; Wang, J.T.; Ramage, D.; Amin, N.; Schwikowski, B.; Ideker, T. Cytoscape: A software environment for integrated models of biomolecular interaction networks. Genome Res. 2003, 13, 2498-2504. [CrossRef]

43. Laskowski, R.A.; Swindells, M.B. LigPlot+: Multiple ligand-protein interaction diagrams for drug discovery. J. Chem. Inf. Model. 2011, 51, 2778-2786. [CrossRef]

44. Garcia-Bustos, V.; Cabanero-Navalon, M.D.; Ruiz-Saurí, A.; Ruiz-Gaitán, A.C.; Salavert, M.; Tormo, M.Á.; Pemán, J. What Do We Know about Candida auris? State of the Art, Knowledge Gaps, and Future Directions. Microorganisms 2021, 9, 2177. [CrossRef] [PubMed]

45. Dejani, N.N.; Elshabrawy, H.A.; Bezerra Filho, C.d.S.M.; de Sousa, D.P. Anticoronavirus and Immunomodulatory Phenolic Compounds: Opportunities and Pharmacotherapeutic Perspectives. Biomolecules 2021, 11, 1254. [CrossRef] [PubMed]

46. Ren, B.; Xia, B.; Li, W.; Wu, J.; Zhang, H. Two novel phenolic compounds from Stenoloma chusanum and their antifungal activity. Chem. Nat. Compd. 2009, 45, 182-186. [CrossRef]

47. Alves, D.D.N.; Ferreira, A.R.; Duarte, A.B.S.; Melo, A.K.V.; de Sousa, D.P.; de Castro, R.D. Breakpoints for the Classification of Anti-Candida Compounds in Antifungal Screening. Biomed Res. Int. 2021, 2021, 6653311. [CrossRef]

48. Singh, S.; Brocker, C.; Koppaka, V.; Chen, Y.; Jackson, B.C.; Matsumoto, A.; Thompson, D.C.; Vasiliou, V. Aldehyde dehydrogenases in cellular responses to oxidative/electrophilic stress. Free Radic. Biol. Med. 2013, 56, 89-101. [CrossRef]

49. Schmid, F.X.; Mayr, L.M.; Mücke, M.; Schönbrunner, E.R. Prolyl isomerases: Role in protein folding. Adv. Protein Chem. 1993, 44, 25-66. [CrossRef] [PubMed] 
50. Li, Z.; Li, H.; Devasahayam, G.; Gemmill, T.; Chaturvedi, V.; Hanes, S.D.; van Roey, P. The structure of the Candida albicans Ess1 prolyl isomerase reveals a well-ordered linker that restricts domain mobility. Biochemistry 2005, 44, 6180-6189. [CrossRef]

51. Samaranayake, D.; Atencio, D.; Morse, R.; Wade, J.T.; Chaturvedi, V.; Hanes, S.D. Role of Ess1 in growth, morphogenetic switching, and RNA polymerase II transcription in Candida albicans. PLoS ONE 2013, 8, e59094. [CrossRef] [PubMed]

52. Becker, J.M.; Kauffman, S.J.; Hauser, M.; Huang, L.; Lin, M.; Sillaots, S.; Jiang, B.; Xu, D.; Roemer, T. Pathway analysis of Candida albicans survival and virulence determinants in a murine infection model. Proc. Natl. Acad. Sci. USA 2010, 107, 22044-22049. [CrossRef] [PubMed]

53. Li, X.; Hou, Y.; Yue, L.; Liu, S.; Du, J.; Sun, S. Potential Targets for Antifungal Drug Discovery Based on Growth and Virulence in Candida albicans. Antimicrob. Agents Chemother. 2015, 59, 5885-5891. [CrossRef] [PubMed]

54. McCarthy, M.W.; Kontoyiannis, D.P.; Cornely, O.A.; Perfect, J.R.; Walsh, T.J. Novel Agents and Drug Targets to Meet the Challenges of Resistant Fungi. J. Infect Dis. 2017, 216, S474-S483. [CrossRef]

55. Ahmad Khan, M.S.; Alshehrei, F.; Al-Ghamdi, S.B.; Bamaga, M.A.; Al-Thubiani, A.S.; Alam, M.Z. Virulence and biofilms as promising targets in developing antipathogenic drugs against candidiasis. Future Sci. OA 2020, 6, FSO440. [CrossRef] [PubMed]

56. Alonso-Monge, R.; Navarro-García, F.; Román, E.; Negredo, A.I.; Eisman, B.; Nombela, C.; Pla, J. The Hog1 mitogen-activated protein kinase is essential in the oxidative stress response and chlamydospore formation in Candida albicans. Eukaryot. Cell 2003, 2, 351-361. [CrossRef]

57. Neto, J.B.A.; da Silva, C.R.; Nascimento, F.B.S.A.; Sampaio, L.S.; da Silva, A.R.; de Freitas, D.D.; Campos, R.S.; de Andrade, L.N.D.; Gonçalves, T.B.; Nagao-Dias, A.T.; et al. Screening of Antimicrobial Metabolite Yeast Isolates Derived Biome Ceará against Pathogenic Bacteria, Including MRSA: Antibacterial Activity and mode of Action Evaluated by Flow Cytometry. Int. J. Curr. Microbiol. App. Sci. 2015, 4, 459-472.

58. Clinical and Laboratory Standards Institute. Reference Method for Broth Dilution Antifungal Susceptibility Testing of Yeasts; CLSI: Wayne, PA, USA, 2012.

59. Araújo, M.O.; Pérez-Castillo, Y.; Oliveira, L.H.G.; Nunes, F.C.; de Sousa, D.P. Larvicidal Activity of Cinnamic Acid Derivatives: Investigating Alternative Products for Aedes aegypti L. Control. Molecules 2020, 26, 61. [CrossRef] [PubMed]

60. Lopes, S.P.; Castillo, Y.P.; Monteiro, M.L.; Menezes, R.R.P.P.B.; Almeida, R.N.; Martins, A.M.C.; de Sousa, D.P. Trypanocidal Mechanism of Action and in silico Studies of $p$-Coumaric Acid Derivatives. Int. J. Mol. Sci. 2019, 20, 5916. [CrossRef]

61. Keiser, M.J.; Roth, B.L.; Armbruster, B.N.; Ernsberger, P.; Irwin, J.J.; Shoichet, B.K. Relating protein pharmacology by ligand chemistry. Nat. Biotechnol. 2007, 25, 197-206. [CrossRef] [PubMed]

62. Altschul, S.F.; Madden, T.L.; Schäffer, A.A.; Zhang, J.; Zhang, Z.; Miller, W.; Lipman, D.J. Gapped BLAST and PSI-BLAST: A new generation of protein database search programs. Nucleic Acids Res. 1997, 25, 3389-3402. [CrossRef]

63. Skrzypek, M.S.; Binkley, J.; Binkley, G.; Miyasato, S.R.; Simison, M.; Sherlock, G. The Candida Genome Database (CGD): Incorporation of Assembly 22, systematic identifiers and visualization of high throughput sequencing data. Nucleic Acids Res. 2017, 45, D592-D596. [CrossRef] [PubMed]

64. Perez-Castillo, Y.; Lima, T.C.; Ferreira, A.R.; Silva, C.R.; Campos, R.S.; Neto, J.B.A.; Magalhães, H.I.F.; Cavalcanti, B.C.; Júnior, H.V.N.; de Sousa, D.P. Bioactivity and Molecular Docking Studies of Derivatives from Cinnamic and Benzoic Acids. Biomed Res. Int. 2020, 2020, 6345429. [CrossRef] [PubMed]

65. Hawkins, P.C.; Skillman, A.G.; Warren, G.L.; Ellingson, B.A.; Stahl, M.T. Conformer generation with OMEGA: Algorithm and validation using high quality structures from the Protein Databank and Cambridge Structural Database. J. Chem. Inf. Model. 2010, 50, 572-584. [CrossRef]

66. Hawkins, P.C.D.; Skillman, A.G.; Warren, G.L.; Ellingson, B.A.; Stahl, M.T. OMEGA. Santa Fe, NM: OpenEye Scientific Software. 2021. Available online: http:/ / www.eyesopen.com (accessed on 15 September 2021).

67. QUACPAC. OpenEye Scientific Software, Santa Fe, NM. Available online: http:/ / www.eyesopen.com (accessed on 16 September 2021).

68. Waterhouse, A.; Bertoni, M.; Bienert, S.; Studer, G.; Tauriello, G.; Gumienny, R.; Heer, F.T.; de Beer, T.A.P.; Rempfer, C.; Bordoli, L.; et al. SWISS-MODEL: Homology modelling of protein structures and complexes. Nucleic Acids Res. 2018, 46, W296-W303. [CrossRef]

69. Jones, G.; Willett, P.; Glen, R.C.; Leach, A.R.; Taylor, R. Development and validation of a genetic algorithm for flexible docking. J. Mol. Biol. 1997, 267, 727-748. [CrossRef] [PubMed]

70. Case, D.A.; Belfon, K.; Ben-Shalom, I.Y.; Brozell, S.R.; Cerutti, D.S.; Cheatham, T.E.; Cruzeiro, V.W.D.; Darden, T.A.; Duke, R.E.; Giambasu, G.; et al. AMBER 2020; University of California: San Francisco, CA, USA, 2020.

71. Pang, Y.P. Successful molecular dynamics simulation of two zinc complexes bridged by a hydroxide in phosphotriesterase using the cationic dummy atom method. Proteins 2001, 45, 183-189. [CrossRef] [PubMed]

72. Walker, R.C.; de Souza, M.M.; Mercer, I.P.; Gould, I.R.; Klug, D.R. Large and fast relaxations inside a protein: Calculation and measurement of reorganization energies in alcohol dehydrogenase. J. Phys. Chem. B 2002, 106, 11658-11665. [CrossRef]

73. Pavelites, J.J.; Gao, J.; Bash, P.A.; Mackerell, A.D., Jr. A molecular mechanics force field for NAD+ NADH, and the pyrophosphate groups of nucleotides. J. Comput. Chem. 1998, 18, 221-239. [CrossRef] 